of the nicker beans had remains of a polyzoan on them, and were sometimes quite covered.

Although the number and variety seem to be unusual, this is not the first time that tropical seeds have drifted to New Zealand. It was known in Auckland thirty or so years ago that nicker beans were cast up on the coasts of North Auckland from time to time. The newspaper report refers to present conditions as "a reversion to an earlier pattern of ocean currents" and says "in greater profusion than in past years all sorts of tropical flotsam are being cast up".

Seven out of twenty-two seeds of Entada sown at Lincoln, Christchurch, in November 1956, germinated about 21 months later. Two of the plants are now growing in the glasshouses, one a vine $4 \mathrm{ft}$. long, the other $8 \mathrm{ft}$. Another plant in the tropical house, Botanic Gardens, Christchurch, is $12 \mathrm{ft}$. long. In North Auckland plants have been grown successfully outdoors by local farmers, and one plant is reported to have grown to a great height. As Entada sp. in Fiji is most characteristically found in the mangrove formation and also grows in the forest ${ }^{1}$, it seems unlikely that it will become established of its own accord on the Ninety Mile Beach, an exposed shore backed by sand-dune country.

The candlenuts were either empty or the seed had decayed into a soft oily mass, as reported previously for seeds of this species carried by ocean currents.

Botany Division,
R. Mason
Department of Scientific and
Industrial Research,
Private Bag,
Christchurch, New Zealand.
' Ridley, H. N., The Dispersal of Plants throughout the World (L.
Reeve and Co., 1930).
"The Christchurch Star-Sun, 12 (April 2, 1957).

\section{Classification of the Tea Plant}

DR. W. WraHT, referring to Watt and Mann's categories of leaf-form within the Assam variety of tea plant", goes on to say: "Number of leaf veins was emphasized; but this has not proved to be a satisfactory criterion". I may say at once that Watt was solely responsible for the leaf vein idea for separating the varieties of tea. When I wrote, with him, the second edition of the Pests and Blights of the Tea Plant I had to include the leaf vein idea, but I never was, myself, able to make anything out of it. I never agreed with Watt on this subject, and it was included in our book in deference to him. Thus, so far as I am concerned, the number of leaf veins was an unsatisfactory criterion fifty-seven years ago.

\section{Bivia, Woodside, \\ Aspley Guise, Bletchley.}

${ }^{1}$ Wight, W., Nature, 183, 1726 (1959).

\section{Staining Reaction of the Pit Membrane of Wood Cells}

IN a recent paper Harada and Wardrop ${ }^{1}$ report that the lignin content of the ray parenchyma cell walls of Cryptomeria japonica (Linnæus fil.) Don. is about 43.5 per cent and also that the lignin is distributed nearly uniformly through the cell walls.
In view of the bearing on their observations and also the possible relation to the movement of materials through wood, the results of the reaction of the pit membrane when wood sections are treated with differential stains are recorded.

Radial longitudinal sections of approximately $10 \mu$ were stained with safranin and fast green according to the following schedule: (1) Sections warmed with aqueous safranin for 3-5 min.; (2) washed with several changes of water and then dehydrated in the normal way with ethyl alcohol; (3) stained with fast green in clove oil for approximately $15 \mathrm{sec}$. (this time can be increased with dilute fast green); (4) washed with clove oil, cleared with xylene and mounted in canada balsam. Washing was continued until the wash liquid was colourless.

In the following species the pit membranes of the ray parenchyma to tracheid pits were stained green in contrast to the red stained unpitted wall :

$P$ inus radiata D. Don, $P$. khaysa Royle, Pseudotsuga menziesii (Mirb.) Franco, C. japonica, Callitris hugelii (Carr) Franco, Abies lasiocarpa (Hooker) Nuttall. The pit membranes of the ray tracheid to tracheid pits were not differentiated to the same degree as the ray parenchyma pit membrane. Both in $P$. radiata and $C$. hugelii the torus of the bordered pits of the tracheids was stained green.

With the following species the membranes of the ray parenchyma to vessel pits and the parenchyma pits generally were differentiated green in contrast to the unpitted cell wall, which was stained red:

Sloanea woollsii F. Muell., Elaeocarpus grandis F. Muell., Cryptocarya glaucescens R. Br., Flindersia schottiana F. Muell., Toona australis Harms, Sterculia acerifolia A. Cunn., Eucalyptus viminalis Labill., E. pilularis Sm., E. microcorys F. Muell. Due to their small size the pit membranes of the fibres were hard to detect, but in a number of the above species a distinct green coloration was obtained. Of the species examined, only Nothofagus moorei J. H. Maiden failed to show differentiation of the pit membrane of the ray-vessel pits. The pit membrane in this species appeared to be masked by abundant polyphenolic materials.

Where possible, sapwood rather than heartwood was used for these observations as it was found that the polyphenolic materials deposited during the transition from sapwood to heartwood obscured the pit membrane, showing instead a red stain with the safranin.

According to Johansen ${ }^{2}$, safranin and fast green adequately differentiate lignified and non-lignified tissue, so that this differentiation indicates that the pit membranes in a number of cells are not lignified. This observation is interesting, as it is those layers which make up the pit membrane, namely, the primary wall and middle lamella, which have the highest concentration of lignin in the unpitted cell walls. The pit membrane, therefore, retains the unlignified condition of the newly differentiated cell wall and explains how the remarkable expansion of the pit membrane which occurs during tyloses is possible. The tylosed pit membrane in Angophora costata Domin. and E. microcorys on the basis of the above staining reaction did not appear to be lignified.

While Liese ${ }^{4}$ and Harada et al. ${ }^{5}$ describe encrusting material present in the pit membrane, it would appear that this material is not lignin. The absence of lignin in the pit membrane has been indicated by means of other techniques by A. B. Wardrop (private communication). The fact that lignin is confined to those parts of the wall where a secondary wall is 